Proceeding of the $2^{\text {nd }}$ International Conference on Agriculture, Food Security and Safety, Vol. 2, 2021, pp. 66-75 Copyright ${ }^{\circ} 2021$ iConferences

ISSN 2682-7158

DOI: https://doi.org/10.32789/agrofood.2021.1006

\title{
Groundwater Quality Assessment in Anuradhapura for Domestic Purposes
}

\author{
Gamage K.H.I ${ }^{1}$, Wickramasinghe R.S.R ${ }^{1}$, Gamage I.M.C ${ }^{2}$
}

${ }^{1}$ Faculty of Graduate Studies, Department of Chemistry, University of Kelaniya, Sri Lanka, kharshana572@gmail.com, roshayaw@gmail.com

${ }^{2}$ Faculty of Agriculture, University of Ruhuna, Sri Lanka, maheshachathushanki@yahoo.com 


\title{
GROUNDWATER QUALITY ASSESSMENT IN ANURADHAPURA FOR DOMESTIC PURPOSES
}

\begin{abstract}
The North central province plays the main agricultural role in Sri Lanka as a developing agricultural-based economy country in the world. Excessive amount of nitrate and fluoride in groundwater consumption is becoming a crucial issue on human health in Sri Lanka, especially in the North Central part of the country. Dental fluorosis and skeleton fluorosis are the major health impacts based on an excessive amount of fluoride as well as presumption on causing chronic kidney disease (CKD). Nitrogenous compounds in groundwater for drinking have been considered possible risk factors for oesophageal cancer and haemoglobinemia or blue baby syndrome. Human activities and natural processes have polluted groundwater. Having a lack of understanding of the actual need for fertilizer, farmers usually tend to apply the surplus amount, thus increasing nitrogen pollution. Accordingly, this research was conducted to deepen the understanding of the distribution of fluoride and nitrate in groundwater in the Anuradhapura area in terms of geological and anthropogenic influences on groundwater quality. Well water samples were collected from intensive agricultural activity areas in Anuradhapura. Physical and chemical parameters were analyzed to identify whether the higher nitrate and fluoride or any compound of a mixture of heavy metals such as cadmium and/ or arsenic is the actual cause for kidney and other health-related issues among the community. Water samples' pHs were in the range of 6.7-7.7. All the wells can be categorized as low salinity water. Turbidity average of 3.51 NTU range of 1-8 NTU was found to be mainly contributed by nitrate at the average of $28.725 \mathrm{mg} / \mathrm{L}$ and ranged from $(22-131) \mathrm{mg} / \mathrm{L}$ of nitrate. In addition, fluorite was found high in Anuradhapura with an average of $0.6 \mathrm{mg} / \mathrm{L}$ and ranged from $(0.4-1.7) \mathrm{mg} / \mathrm{L}$. Sulphate level was also high with an average of $178 \mathrm{mg} / \mathrm{L}$ and ranged from $(58-505 \mathrm{mg} / \mathrm{L})$. There was no significant effect of heavy metals such as cadmium, arsenic, iron, and copper concentrations which were below the permissible level of $0.01 \mathrm{mg} / \mathrm{L}$. The research clearly indicates the abundance of nitrate and fluoride in groundwater, especially in the dry zone. The major sources are fluoridebearing minerals in bedrock and soil zone. In addition to that, the influence of agriculture which causes excessive nitrate levels in groundwater, is apparent, irrespective of climatic zones.
\end{abstract}

Keywords: Groundwater quality, fluoride, nitrate, Chronic kidney disease

\section{Introduction}

Groundwater is a major water consumption source of human in Sri Lanka as most of the dry zones in Sri Lanka mainly depend on groundwater sources because of the lack of other freshwater sources. Therefore, groundwater contamination is considered a major problem when it is used for drinking purposes. Human activities and natural processes can pollute groundwater. Nitrate and fluoride play major roles in inorganic pollutants in groundwater. Consumption of water with excessive fluoride and nitrate in groundwater is becoming a crucial issue for human health in Sri Lanka. Excessive fluoride in water may cause dental fluorosis, skeleton fluorosis, and chronic kidney disease (CKD). Groundwater quality was analyzed in areas that have been recognized mostly as agricultural and urban areas in the Anuradhapura district. 
Gamage K.H.I / Ground water quality assessment in Anuradhapura for domestic purposes

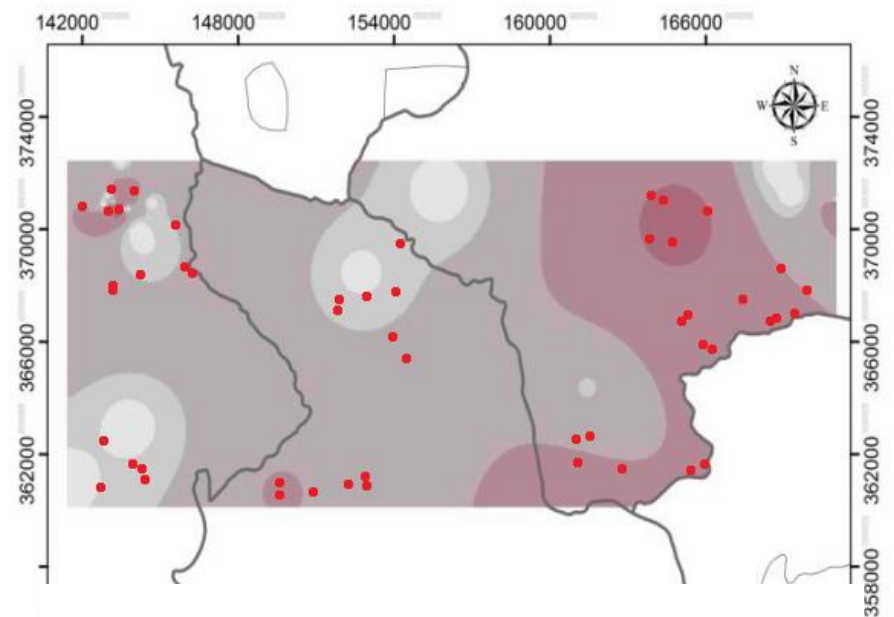

Figure 1 Location of the samples collected areas in Anuradhapura District, including Urban cities, Agricultural areas, Residence areas

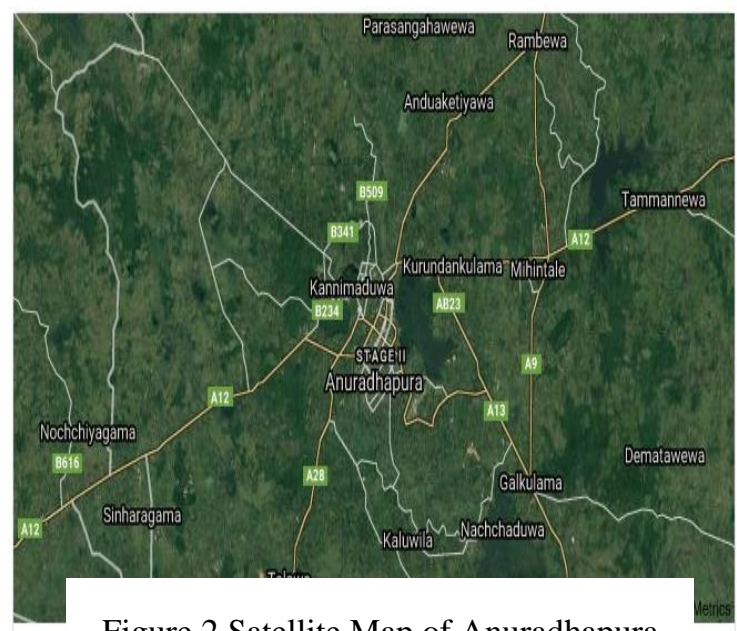

Figure 2 Satellite Map of Anuradhapura District.

Six main types of groundwater aquifers have been identified and characterized in Sri Lanka. Of these, five aquifers are associated with the coastal region of Sri Lanka (Panabokke and Perera, 2005).

1. Shallow karstic limestone aquifer of Jaffna Peninsula.

2. Deep confined aquifer.

3. Coastal sand aquifer.

4. Alluvial aquifer.

5. South-Western Lateritic (Cabook) Aquifer.

6. Shallow Regolith Aquifer of the Hard Rock Region.

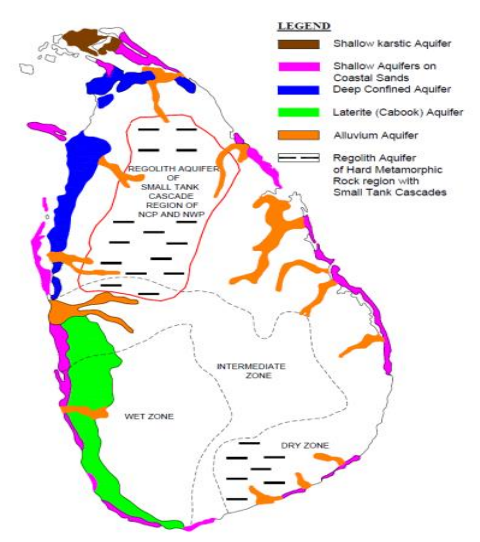

Figure 3: Main aquifers in Sri Lanka Source: Panabokke and Perera, (2005) 
Consumption of water with excessive fluoride and nitrate in groundwater is becoming a crucial issue for human health in Sri Lanka. According to the Sri Lanka Groundwater Quality Standard guideline, the maximum admissible concentration of nitrate in drinking water is $50 \mathrm{mg} / \mathrm{L}$ as nitrate, and the permissible level of fluoride in drinking water is $1.5 \mathrm{mg} / \mathrm{L}$. Dental fluorosis and skeleton fluorosis are the major health impacts based on an excessive amount of fluoride as well as hypothesized as causing chronic kidney disease (CKD). On the other hand, the excessive usages of nitrate and unplanned disposal of wastes increased nitrate levels significantly in many countries, including Sri Lanka. Nitrate pollutants are anthropogenic in nature, and fluoride pollutants are naturally occurring ones. Nitrate pollutions can reach the groundwater through two types of sources, point sources and nonpoint sources. Septic tanks and toilet pits are known as point sources. Agricultural areas and other sources are identified as non-point sources. Fluoride can reach the groundwater by the solubility of fluoride minerals. There are fewer possibilities that fluoride is an anthropogenic pollutant in Sri Lanka. Most of the fluoride minerals are less soluble. The solubility of these fluoride minerals can be changed by various factors such as subsurface temperature. The study of the Dissanayake et al. (1985) on Jaffna, Nuwara Eliya, and Puttalam districts showed serious nitrate pollution in the groundwater of these districts. The excess usages of nitrate fertilizers and high population density are behind these effects. Fluoride in groundwater is the major issue in the Anuradhapura district. Fluoride minerals such as apatite are highly present in the dry zone areas of this district. Land use means how humans make use of the earth's surface. It also has been defined as "the arrangements, activities, and inputs people undertake in a certain land cover type to produce, change or maintain it" (FAO, 1997a; FAO/UNEP, 1999). In the Anuradhapura district, residential land use includes areas that are used for residential purposes. Residential uses are intensive agriculture, and commercial land uses in urban areas include business zones and shopping centers. Commercial facilities are only found in urban areas. Industrial land use pattern includes industrial zones, transportation, oil and gas, communication, and utility facilities. Institutional lands are mainly devoted to institutional and recreational. This category includes public parks, grounds, schools, temples and churches, and public buildings; cultural land uses are paddy fields, pastures, other growing croplands and also includes land use for livestock such as cattle, milk cows, etc. Non-forest lands are defined as areas supporting the early stages of plant succession consisting of plant communities identified by grasses or shrubs. Samples were collected by covering residential, commercial, industrial, institution/recreation, while the main focus was on the agricultural areas.

\section{Aims/Objective}

Well water samples were collected from intensive agricultural activity areas in Anuradhapura. Physical and chemical parameters were analyzed to identify whether the high nitrate, fluoride, or any compound of a mixture of heavy metals such as cadmium and/ or arsenic is the actual cause for kidney and other health-related issues among the community. The nitrate and fluoride concentrations in the groundwater of Anuradhapura were compared with WHO and SLS standards. Analysis of groundwater quality to identify major differences in nitrate and fluoride concentration in groundwater compared to past data was also conducted. 
Gamage K.H.I / Ground water quality assessment in Anuradhapura for domestic purposes

\section{Materials and Method}

Feedback forms were filled to collect information regarding water-related issues involving intensive agricultural activity areas in Anuradhapura. A total of 105 groundwater samples were collected from 35 wells randomly from the selected areas. Three samples were collected from each well, and the average was calculated. GPS coordinates were also recorded for the exact locations of the wells. Samples were taken from December 2018 to September 2019. Water samples were filtered through a $0.45 \mu \mathrm{m}$ bacteria membrane filter and stored in a plastic container. Three drops of concentrated sulphuric acid were also added to the samples. Finally, the containers were properly sealed and transferred to the chemistry laboratory for further analysis. Coordinates: A GPS system was used to take the GPS coordinates. Turbidity: Electronic nephelometer was used to measure the turbidity. Nephelometric measurements were reported as nephelometric turbidity units (NTU). For measurement of turbidity, the sample was agitated gently until air bubbles disappeared, and the sample was poured into a cell for measurement. $\mathrm{pH}$ : Electronic $\mathrm{pH}$ meter was used to measure the $\mathrm{pH}$. Conductivity: A conductivity meter was used to measure the conductivity in a unit of millisiemens per centimeter $(\mathrm{mS} / \mathrm{cm}) . \mathrm{NO}^{-}$analysis: Ultraviolet Spectrophotometric Screening Method was used. Spectrophotometric measurement: Absorbance or transmittance was read against redistilled water set at zero absorbance or $100 \%$ transmittance. Sulphate Analysis: Turbidimetric method. Analysis of metals: Copper, cadmium, and iron concentrations were measured by the Atomic Absorption spectrophotometer (AAS). Direct Air-Acetylene Flame Method was used to analyze the water samples. Nitrate and Fluoride ions in the groundwater were interpolated using the Inverse Distance Weighted method aided by ArcGIS 9.3 software to visualize the data

\section{Results and Interpretation}

The groundwater $\mathrm{pH}$, conductivity, and turbidity were the basic parameters analyzed during the groundwater sample collection.

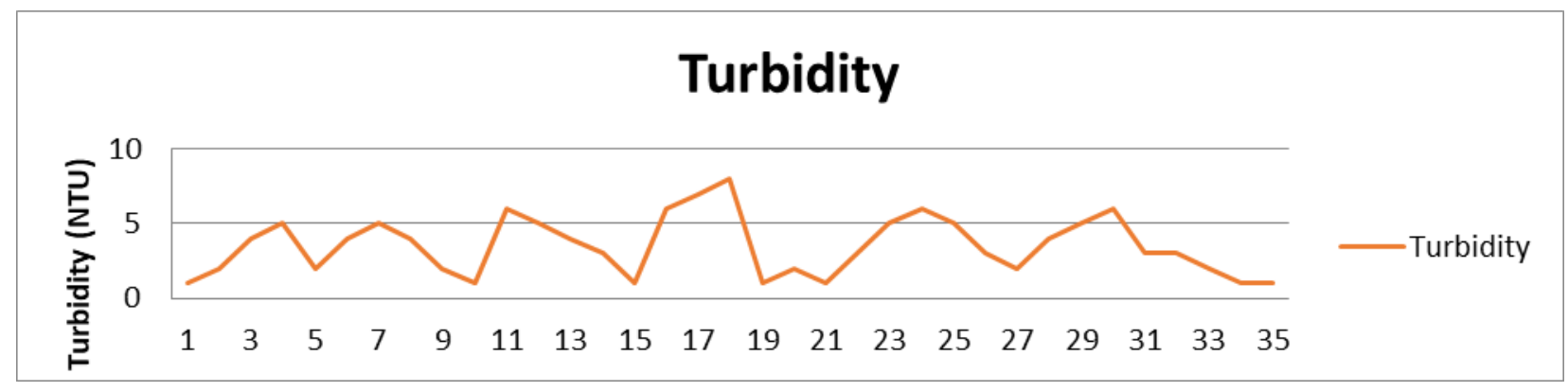

Figure 4 Average turbidity distribution pattern in selected water samples 


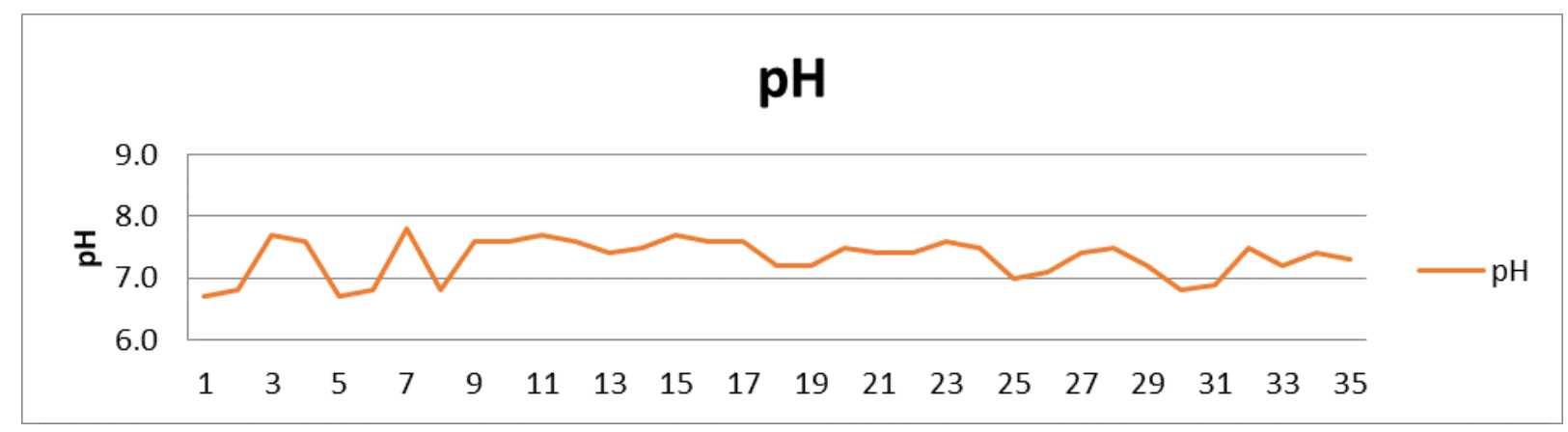

Figure 5 Average $\mathrm{pH}$ distribution pattern in selected water samples

Turbidity variation is between $0-10$ as a whole. Interpolation of $\mathrm{pH}$ shows a small part of research area $\mathrm{pH}$ variation is in between $6-9$ as a whole. Interpolation of $\mathrm{pH}$ shows a small part of research area ranging the $\mathrm{pH}$ in between $10-14$. Conductivity ranged from $15-61 \mathrm{mS} / \mathrm{cm}$.

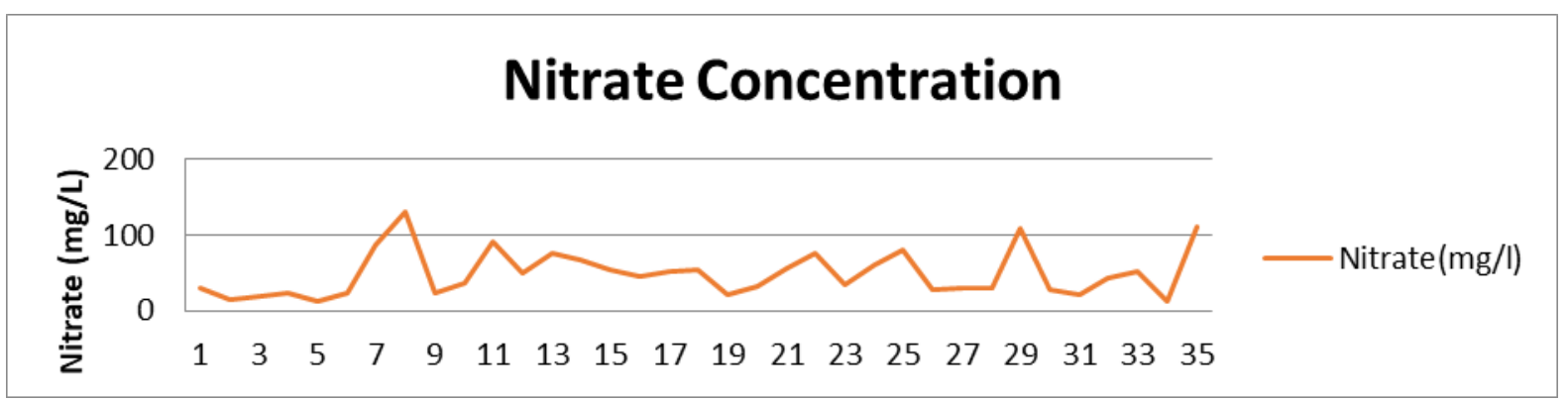

Figure 6 Average nitrate distribution pattern in selected water samples

The nitrate varies between $22 \mathrm{mg} / \mathrm{L}$ to $131 \mathrm{mg} / \mathrm{L}$ as nitrate. A total of 105 water samples from 35 wells were measured. Results show that $84 \%$ of well waters were with nitrate content of less than 20 $\mathrm{mg} / \mathrm{L}$ and $12 \%$ were of moderate risk ranging from $20 \mathrm{mg} / \mathrm{L}$ to $30 \mathrm{mg} / \mathrm{L}$ and $3.6 \%$ were with values of above $50 \mathrm{mg} / \mathrm{L}$.

\section{Flouride Concentration}

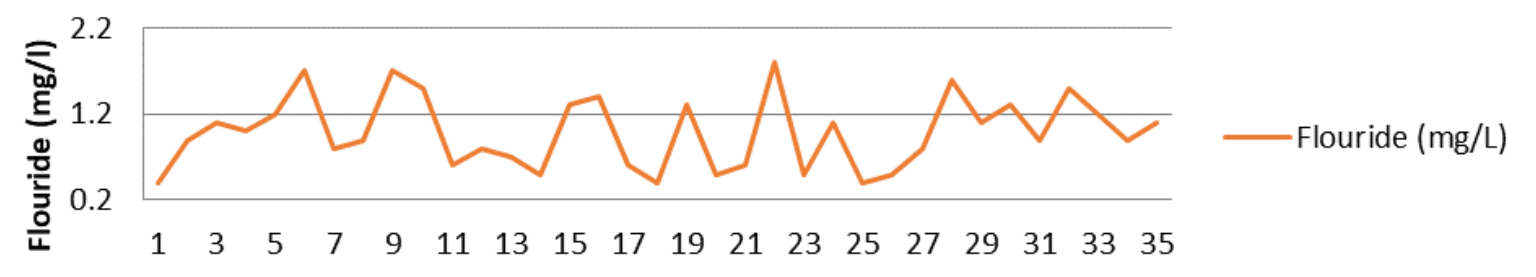

Figure 7 Average fluoride distribution pattern in selected water samples 
The range of fluoride in groundwater is $0.4 \mathrm{mg} / \mathrm{L}$ to $1.8 \mathrm{mg} / \mathrm{L}$. The percentage value of well water under the maximum desirable level was $17 \%$, and $45 \%$ were in the range of $0.6 \mathrm{mg} / \mathrm{L}$ to $1.0 \mathrm{mg} / \mathrm{L}$, and $38 \%$ were in the critical range of $1.0 \mathrm{mg} / \mathrm{L}$ to $1.8 \mathrm{mg} / \mathrm{L}$.

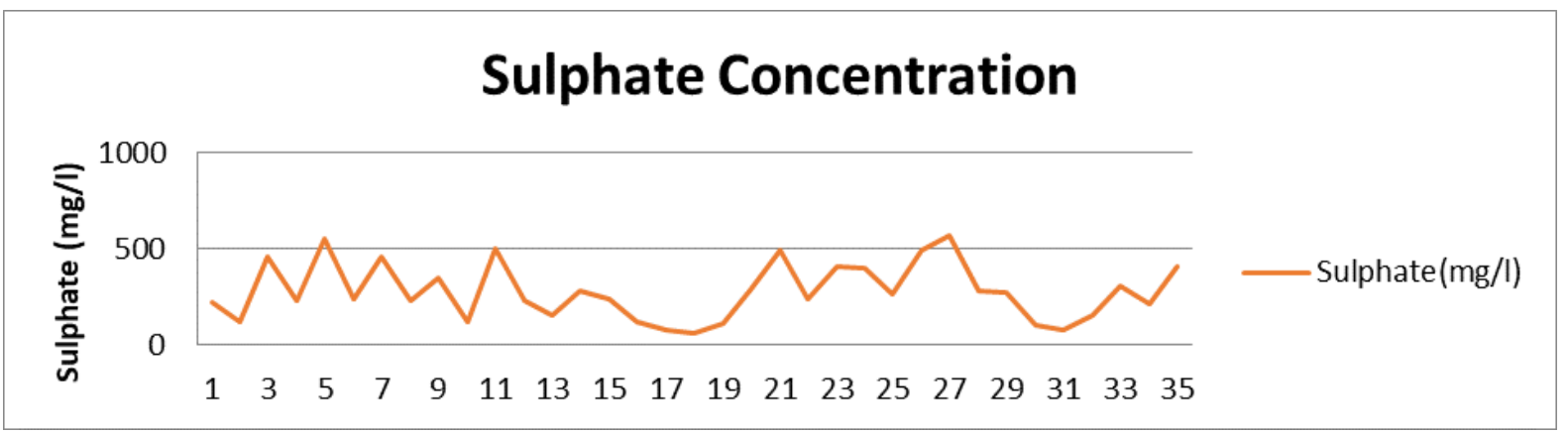

Figure 8 Sulphate distribution pattern in selected water samples

The range of sulphate is $58 \mathrm{mg} / \mathrm{L}$ to $572 \mathrm{mg} / \mathrm{L}$ in groundwater. The percentage of well water under the level of $250 \mathrm{mg} / \mathrm{L}$ is $21 \%$, and $67 \%$ were in the range of $250 \mathrm{mg} / \mathrm{L}$ to $500 \mathrm{mg} / \mathrm{L}$, and $12 \%$ were in the critical range over $500 \mathrm{mg} / \mathrm{L}$.

The interpolation of bicarbonate concentration of the research groundwater in the research areas was having bicarbonate concentrations ranging from 31 to $43 \mathrm{mg} / \mathrm{L}$. Interpolation of concentrations of heavy metals such as arsenic (As) and copper $(\mathrm{Cu})$ was calculated by using ICP-OES and were well under the permissible level $0.01 \mathrm{mg} / \mathrm{L}$, and most of the sample were not detected.

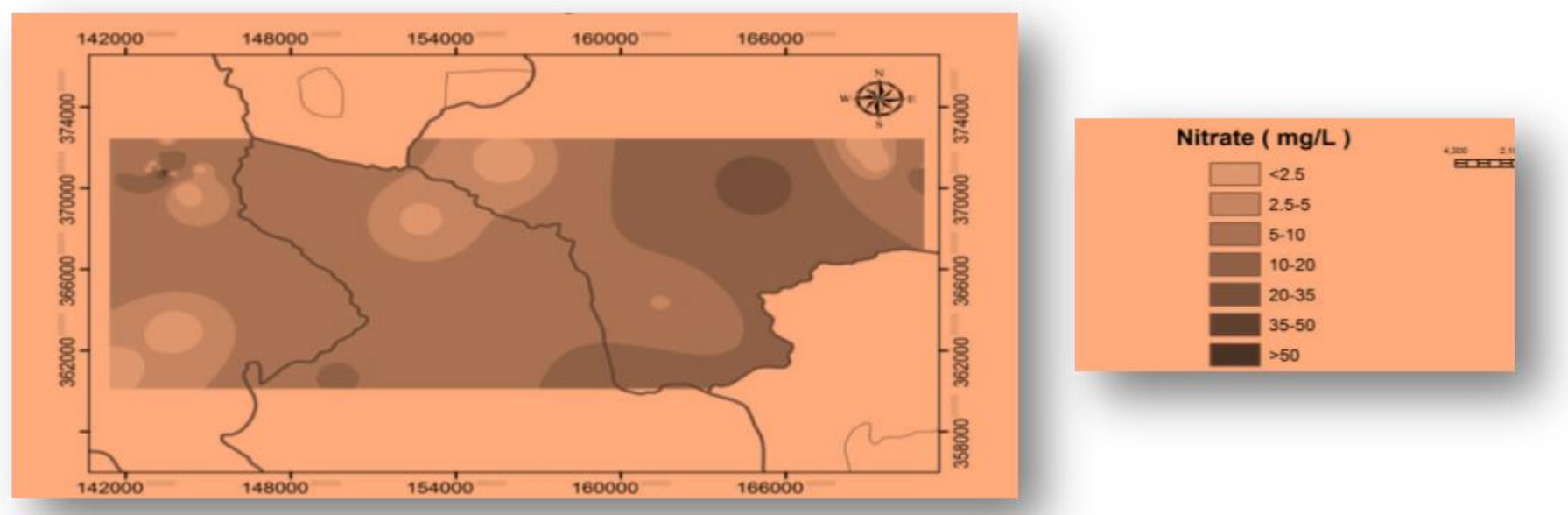

Figure 9 Nitrate distribution pattern - Anuradhapura 


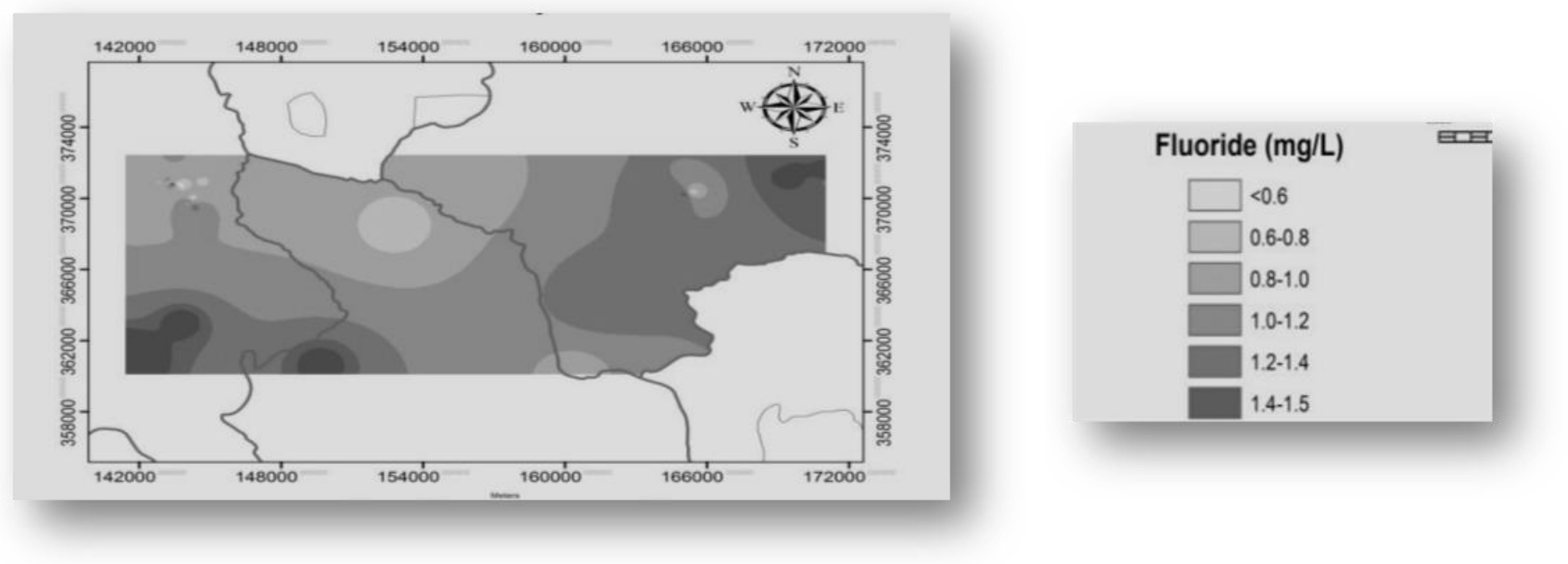

Figure 10 Fluoride distribution pattern - Anuradhapura

\section{Discussion}

Groundwater quality assessment was carried out in intensive agricultural activity areas in Anuradhapura to study the suitability of shallow groundwater for domestic and drinking purposes. This research was conducted to identify the drinking water and domestic water-related problems according to the feedback from the people in Anuradhapura. To identify the possibility of drinking water effectively on kidney-related lines such as Colour Chronic Kidney Disease(CKDu), diarrhoea, a possible risk factor for oesophageal cancer and blue baby syndrome and other water-related diseases. Results of all the study agricultural activity areas on several physical and chemical parameters showed that water is not suitable for drinking and domestic purposes. Well water from intensive agricultural activity areas in Anuradhapura and intermediate zones is not suitable for drinking and domestic purposes. Unlike rivers, aquifers do not have any self-cleansing capacity, especially with respect to aeration. Hence, once polluted, they remain polluted for long periods. People need instructions to use rainwater collected by a recommended rainwater harvesting system until the water supply is provided for this community for drinking and domestic purposes. When we consider it, the Anuradhapura area has a shallow aquifer of the peninsula, which occurs in the channels and cavities of the Miocene Limestone. All the shallow groundwater found within the cavities originates from the infiltration of rainfall, and this shallow groundwater forms mounds or lenses floating over the saline water. These water mounds or lenses reach their peak during the monsoon rains of November -December. The major sources are fluoride-bearing minerals in bedrock and soil zone. In addition to that, the influence of agriculture, excessive nitrate levels in groundwater is apparent irrespective of climatic zones. Nitrate is easily dissolved in water, and it is very difficult to remove. Fluoride has less solubility other than first group fluoride. Simple household treatment methods for other contaminations such as boiling, filtration, disinfection, and water softening are not effective for nitrate and fluoride removal. 
Gamage K.H.I / Ground water quality assessment in Anuradhapura for domestic purposes

Boiling will actually increase both nitrate and fluoride concentration of the remaining water. Water treatments include distillation, reverse osmosis, ion exchange. The presence of soluble and/or labile fluoride in soils is the major controlling factor for the fluoride levels in groundwater. Soluble fluoride is mainly added by agricultural practices, which substantially increase fluoride levels in soils under acidic $\mathrm{pH}$, mainly due to dissolution of metal fluoride complexes (Manoharan et al., 2007; Zhu et al., 2006). Conversely, under alkaline conditions, soluble fluoride can be retained in the soil (Skjelkvåle, 1994). On the other hand, labile fluoride is contained within mineral phases and can be readily released to groundwater at any $\mathrm{pH}$ (Larsen and Widdowson, 1971). Hence, weathering conditions and the maturity of soils are the main governing factors for the availability of labile fluoride in soils and subsequent transfer to groundwater (Zhu et al., 2007).

In Sri Lanka, the abundance of fluorite in the rocks and the ease with which it is leached under the effects of groundwater has an important bearing on the abundance of fluorite in the areas concerned and hence the prevalence of dental diseases. The high fluorite concentrations lie in the eastern and north-central regions of the country. (Dissanayake \& Weerasooriya., 1985)

Generally, most groundwater sources have higher fluoride concentrations than surface water. As groundwater percolates through the weathered rock in the aquifers, it dissolves fluoride-bearing minerals, hence, releasing fluoride into solution. The concentration of fluoride in groundwater is varied and depends on the geological formations traversed by water, temperature, $\mathrm{pH}$, the solubility of fluoride bearing minerals, and the presence or absence of other precipitating or complexing ions (Parkhurst et al., 1996). Several factors control the concentration and the migration of the fluoride ion in groundwater. The following illustration shows the mechanism of fluoride migration in arid and semi-arid areas. A study on the relationship between land use and groundwater resources and quality was shown that land use affects groundwater resources through changes in recharge and by changing water demands. Inappropriate land use, particularly poor land management, causes chronic groundwater quality problems. Acute groundwater quality problems are common and arise from unsuitable land use and control, notably through point sources of hazardous chemicals. (Lerner \& Harris, 2009) A review of the impact of land-use change on groundwater revealed that the land-use change pattern reflects the rate of change of groundwater recharge. It also further shows that it is necessary to detect the land-use change in the past and present existing land use, and its spatial distribution and potential changes are essential prerequisites for planning and management. (Mishra, 2013) The usage of the earth surface is directly affected due to the groundwater quality of that particular area. It is because of a couple of reasons; water begins as precipitation (usually rain or snow) at the land surface and infiltrates through soil and rock to become groundwater. The population density and distribution is a factor of availability of groundwater, as well as its quality. High population density poses a threat to groundwater quantity and quality. Also, when the concentration of the population goes high, the municipal sewage systems also impact groundwater quality as leachate of nitrogen from septic systems into the groundwater. The municipal dumping sites also affect groundwater quality. Solid waste creates problems with rain as they infiltrate into the groundwater reservoirs. Most of the other land uses also contaminate groundwater such as releases or spills from stored industrial wastes; from sources below the land surface but above the water table, such as septic systems or leaking underground petroleum storage systems; from structures beneath the water table, such as wells; or from contaminated recharge water. 
Therefore, it is conceivable that there is a significant relationship between land use types and the quality of groundwater. There have not done this kind of study in Sri Lanka before. But the other parts of the world have done these kinds of studies to take advantage of groundwater policy-making decisions and groundwater pollution control. Those are highly applicable, and these models have many applications to the urban environment. Developing these kinds of models is useful to take groundwater policy-making decisions in the urban environment.

\section{Conclusions and Recommendations}

Water samples $\mathrm{pH}$ was in the range of 6.7-7.7. All the wells can be categorized as low salinity water. The conductivity ranges from $15-61 \mathrm{mS} / \mathrm{cm}$, showing low variation throughout the area. Turbidity average of $3.51 \mathrm{NTU}$ range of 1-8 NTU was found in polluted groundwater by nitrate at the average of $28.725 \mathrm{mg} / \mathrm{L}$, and ranged from $22-131 \mathrm{mg} / \mathrm{L}$ as NO3-. In addition, fluorite was found high in Anuradhapura with an average of $0.6 \mathrm{mg} / \mathrm{L}$ and ranged from $0.4-1.7 \mathrm{mg} / \mathrm{L}$. Sulphate level was also high with an average of $178 \mathrm{mg} / \mathrm{L}$ and ranged from $58-505 \mathrm{mg} / \mathrm{L}$. There was no significant effect of heavy metals such as cadmium, arsenic, iron, and copper concentrations which are below the permissible level of $0.01 \mathrm{mg} / \mathrm{L}$. The research clearly indicates the abundance of nitrate and fluoride in groundwater, especially in the dry zone.

\section{References}

Sivarajah, N. (2003). Health related problems of water pollution in Jaffna. International workshop on environmental management in north-east Sri Lanka. 1st- 4th December 2003. Thirunelvely, Jaffna, Sri Lanka. pp 89-94.

World Health Organization (1995), Water Quality Standards for drinking purposes. Comprehensive Report.

Balendran, V.S., C.H.I. Sirimanne, and S. Arumugam., 1968. Groundwater resources of Jaffna Peninsula, Water Resource Board, Colombo.

Bijay-Singh, Yadvinder-Singh and G.S. Sekhon(1995); Fertilizer-N use efficiency and nitrate pollution of groundwater in developing countries; Journal of Contaminant Hydrology

Bogovski P, Bogovski S., 1981. Animal species in which N-nitroso compounds induce cancer. Int J Cancer

Association, A. P. H., Association, A. W. W., Federation, W. P. C., \& Federation, W. E. (1915). Standard methods for the examination of water and wastewater (Vol. 2).American Public Health Association

Mishra, N. (2013). Impact of Land Use Change on Groundwater in Upper Ganga Canal Command. Research \& reviews: Journal of engineering and technology

Mouser, P. J., Rizzo, D. M., Druschel, G. K., Morales, S. E., Hayden, N., O'Grady, P., \& Stevens, L. (2010). Enhanced detection of groundwater contamination from a leaking waste disposal site by microbial community profiles. Water Resources Research, 46(12). 